\title{
Nation Building and the Construction of Identity: Xenophobia in South Africa
}

\author{
JANet E. Reilly
}

\begin{abstract}
This article examines the process of nation building in South Africa and its effect on the rise of xenophobia. It explores the ways in which South Africa's efforts, since the elections of 1994, to construct a non-racial national identity have led to the exclusion of and the denial of rights to non-citizens. Looking at the history of immigration policy in South Africa, it argues that increased levels of xenophobia among South Africans represent an ever-widening gap between the country's attempts to restructure itself constitutionally (by altering its laws) and culturally (by changing the people's perception of what it means to be South African).
\end{abstract}

\section{Résumé}

Cet article examine le processus mis en oeuvre en Afrique $d u$ Sud pour bâtir une nation et ses conséquences sur la montée de la xénophobie. Il explore la question de savoir comment, depuis les élections de 1994, les efforts de l'Afrique du Sud pour façonner une identité nationale nonraciale ont abouti à l'exclusion des non-citoyens et au déni de leurs droits. Considérant l'histoire de l'immigration en Afrique du Sud, l'article soutient que des niveaux accrus de xénophobie parmi les Sud-africains représentent un fossé de plus en plus grandissant entre, d'une part, les efforts de ce pays pour restructurer sa constitution (en changeant ses lois) et de l'autre, son désir d'une restructuration culturelle (en altérant la perception du peuple sur ce que cela signifie d'être Sud-africain).

\section{Introduction}

$\mathrm{I}$ n 1966, the United Nations proclaimed March 21 the International Day for the Elimination of Racial Discrimination, to commemorate the events of March 21, 1960, when South African police opened fire and killed sixty-nine people at a peaceful demonstration against the apartheid "pass laws" in Sharpeville, South Africa. This year, the United Nations used observance of the International Day to focus attention on the upcoming World Conference on Racism, Xenophobia, and Related Intolerance, to be hosted by South Africa in 2001. High on the agenda was the growing concern over the level of xenophobia and increased violence toward those perceived as "foreigners" in South Africa within the past several years. The end of apartheid, though a stunning victory for human rights and democracy, has not translated into the expected end to racial discrimination in South Africa. Why has the transition from apartheid to the "Rainbow Nation" envisioned by Archbishop Desmond Tutu proven fertile ground for xenophobia? The answer can be found in an understanding of the process of nation building and national identity construction. At the same time that South Africa actively seeks to promote itself as a liberal democratic state and to foster ties to the African continent, its efforts to construct its own sense of national identity have led to the exclusion of and the denial of rights to those perceived as "foreigners."

The preamble of South Africa's constitution envisions a "society based on democratic values, social justice, and fundamental human rights." ${ }^{1}$ In the years since the historic all-race democratic elections of 1994, South Africa has embarked on a fervent-and in many ways visionary-restructuring of its policies toward immigration 
and asylum. In an attempt to rid itself of its apartheid legacy, the new government, in 1995, acceded to the 1969 OAU Convention Governing the Specific Aspects of Refugee Problems in Africa and, in 1996, to the 1951 un Convention relating to the Status of Refugees and the 1967 Protocol. Although the universal human rights enshrined in these international documents were reinforced by the Government of National Unity's amendments to South African domestic law, the reality of immigration and asylum in South Africa has proven to be far less enlightened than the rhetoric. Despite the new legal rights afforded to non-citizens within South Africa, the "exclusion policies" established under apartheid continue to be enforced. As the government and the people of South Africa strive to define who is a citizen, the convenient solution has been to focus on who is not. Examining South Africa's immigration policies in their historical context and incorporating an understanding of the process of nation-building, it is evident that the increased levels of xenophobia among South Africans represent an everwidening gap between the country's attempts to restructure itself constitutionally (by altering its laws) and culturally (by changing the people's perception of what it means to be South African).

\section{The Importance of Migrants to South Africa}

From the time of its creation as a state, South Africa has relied heavily upon, and been defined by, the migration of populations across its borders. Based on census figures, South Africa's foreign-born population has always been significant, and it increased steadily during the twentieth century. ${ }^{2}$ For a multiplicity of reasons, African migrants have traditionally flocked to South Africa, attracted by the employment opportunities within South Africa, and driven from neighbouring countries by political and economic instability.

Over the past 150 years, large-scale migration into South Africa has been fuelled by the mining industry's need for unskilled and semi-skilled "contract labour." Tracing the carving up of Africa between the colonial powers to the 1884 Berlin Conference, Kotzé and Hill assert that, in southern Africa, political boundaries failed to coincide with economic boundaries. As a result, large numbers of migrants from neighbouring states recruited to work in South Africa's mines "played an indispensable role in building South Africa's economic infrastructure, while simultaneously (if unwittingly) contributing to the economic decline of their countries of origin." ${ }^{3}$
Historically, foreigners have accounted for at least 40 per cent, and at times up to 80 per cent, of those employed as mine workers in South Africa. ${ }^{4}$ According to Wilson and Ramphele, "Nowhere else in the world has an industrial economy employed for so long such a high proportion of oscillating migrants (coming from both inside and outside the country) in its labour force." 5 One of the reasons that South Africa's mining industry has consistently been able to attract such a large number of foreign workers has been the relative economic inequality that exists between South Africa and its border countries. South Africans are reportedly thirty-six times richer, on average, than Mozambicans - an enormous wealth disparity when compared to the fact that Americans are only seven times richer than Mexicans. ${ }^{6}$

Equally important as the economic "pull" factors within South Africa that have attracted foreign workers, have been the "push" factors-economic and political instability-within neighbouring countries that have driven people out of those countries and into South Africa. The causes of economic stagnation in South Africa's border countries are complex, but an important contributing factor has been the destabilization campaign waged by the apartheid state in South Africa during the 1980s.? According to a highly critical report published recently by Human Rights Watch, the South African government led by President Pieter Willem Botha launched a campaign aimed at destroying the educational, transport, and economic infrastructure in neighbouring African countries, in order to punish neighbouring states for supporting the African National Congress (ANC) and its anti-apartheid movement. ${ }^{8}$ South Africa backed the rebel groups UNITA in Angola and renamo in Mozambique, and intervened directly in Lesotho, Botswana, Angola, and Namibia. The apartheid state also instituted an economic embargo that was particularly destructive to the landlocked states of Swaziland, Lesotho, and Botswana.

As a result of the destabilization campaign during the apartheid era, South Africa's Bantustan regions received large numbers of not only economic migrants, but also refugees from the countries of the Southern African Development Community (SADC). The separate and quasiindependent status of the various "homelands" enabled them to grant refugee status to hundreds of thousands of linguistically and culturally affiliated Africans, especially Mozambicans. Since the dissolution of South Africa's internal borders and the incorporation of the homelands into the South African state, however, the legal status of 
these former refugees has been blurred. As a result, foreignborn people in South Africa, who were once accepted in the homelands, increasingly find themselves the targets of anti-immigrant sentiment, often resulting in violence. While the new government has attempted to rectify this through a series of amnesties granting permanent residence to miners and members of SADC countries resident in South Africa for a specified period of time, countless Africans remain in South Africa without formal status.

\section{The History of Migration Policy in South Africa prior to 1994}

In order to understand the challenges that South Africa currently faces in determining citizenship rights for those within its borders and for those wishing to immigrate, it is necessary to view the present situation in the context of the policies that were developed to control migration prior to, and as part of, the apartheid regime of the twentieth century. As early as 1913, three years after the establishment of the Union, immigration legislation sought to restrict black mobility within South Africa. The Immigration Regulations Act of 1913, South Africa's first nationwide immigration legislation, established an Immigration Board with the power to prohibit the entry of "any person or class of persons deemed by the Minister on economic grounds or on account of standards or habits of life to be unsuited to the requirements of the Union." Subsequent immigration legislation, such as the 1937 Aliens Act, designed to restrict Jewish immigration by requiring work permits for non-citizens, paved the way for the apartheid policies enacted after 1948 .

During the apartheid era, the government attempted to control the movement of non-whites within South Africa through the establishment of the influx control system. All Africans who travelled outside of the Bantustans were required to have a pass, and inability to produce the pass on request was cause for immediate arrest and deportation. The pass laws, which were finally removed in 1986, resulted in over 381,000 Africans being arrested in the year 1975-6, at the height of their use, and in over 12 million arrests over the period from 1948 to $1985 .{ }^{10}$ Referring to the creation of the Bantustan policy, Kotzé and Hill argue that "the domestic result of this economic restructuring was the creation of massive rural settlements of South Africans in refugee-like conditions but robbed of official refugee status under the emerging international refugee regime by the fiction of separate development."

While the system of "separate but equal" never gained any real international legitimacy, it allowed South Africa to maintain an image of itself as an immigration state. At the same time that South Africa sought to restrict black migration and other classes of "prohibited persons" from entering, it openly encouraged white immigration from Germany, Holland, and Britain. During the 1960s, white Nigerians and Angolans fleeing the collapse of colonialism were offered asylum in South Africa. While the simultaneous policies of immigration (primarily white) and exclusion (primarily black) were at odds with one another, they were, in fact, not all that different from the practices of other colonial-settler states. Both the United States, through its National Origins Act, and Australia, through the White Australia policy, sought to control the racial composition of the populations within their territories.

The legacy of the apartheid period and the immigration policies that shaped it are still very evident in the issues facing South Africa today. The 1991 Aliens Control Act, still in effect today, is merely a consolidation of previous acts entrenched in the racism and anti-Semitism of the 1930s. Adopted by the previous administration but amended during the course of the transition to democracy, the Aliens Control Act continues to distinguish between white migrants and black migrants, and extends the power of immigration officers to decide immigration claims, while removing the applicants' rights to appeal their decisions. While the government has worked to enact new immigration legislation and has even invited opinions and comments on its green and white papers, the sections of the Aliens Control Act relating to refugees were replaced only this year by the new Refugees Act of 1998, and the draft white paper on International Migration has yet to be adopted as law.

\section{The Rise of Xenophobia}

While many predicted that the end of apartheid would set in motion the machinery necessary to eliminate racial discrimination in South Africa, the years since 1994 have witnessed a dramatic increase in xenophobia and acts of hostility toward those perceived as "foreigners." Despite the adoption of numerous international conventions, and despite the human rights claims made in the South African Constitution and the new Refugees Act, newspaper headlines attest to the increased violence and negative attitudes toward immigrants, on the part of both government officials and South African citizens. In 1999, a National Plan of Action, called Roll Back Xenophobia, was drafted, encouraging various sectors of society, including government, to get involved in activities to combat xenophobia. The plan, published jointly by the South African 
Human Rights Commission, the National Consortium on Refugee Affairs, the United Nations Human Rights Commission, and the United Nations High Commissioner for Refugees, defined xenophobia as a "deep dislike of non-nationals by nationals."12

An extensive national survey conducted in mid-1997 by the Southern African Migration Project examining South Africans' attitudes toward immigrants and immigration policy found that 25 per cent of South Africans favoured a complete ban on immigration and 45 per cent supported strict limits on the numbers of immigrants permitted to enter the country. Only 17 per cent indicated openness toward a more flexible policy that would be tied to the availability of jobs, and only 6 per cent supported a totally open policy of immigration. According to the survey, the figures represented the highest level of opposition to immigration recorded by any country in the world where comparable questions have been asked. Respondents cited job loss, crime, and disease as the negative consequences they feared from immigrants living in the country, though only 4 per cent recorded interacting on a regular basis with non-citizens in the region. ${ }^{13}$

Although many South Africans are reluctant to admit that the scores of anti-immigrant abuses reported by human rights groups in recent years are motivated by xenophobia, it is clear that those perceived as foreigners are being singled out for abuse. Immigrants are blamed for crime, drugs, and the high level of unemployment. Anyone considered "too black" or who is unable to speak a local language, such as Xhosa or Zulu, is a potential target. Police use extremely unreliable indicators such as inoculation scars to identify someone as a foreigner; as a result, an estimated 20 per cent of those placed in detention on suspicion of being undocumented migrants are eventually released after proving South African citizenship. ${ }^{14}$

Inaccurate representation and "criminalization" of migrants by the media have had a tremendously negative impact on public opinion toward migrants, especially when one considers the small minority of South Africans who report having regular personal contact with noncitizens. A survey drawing on over 1200 English-language clippings about migration from South African newspapers between 1994 and 1998 indicated that "coverage of international migration by the South African press has been largely anti-immigrant and unanalytical ... A large proportion of the articles reproduce racial and national stereotypes about migrants from other African countries ... [which are] made worse by the more subtle use of terms like 'illegal' and 'alien.'”'15
The media, however, are not the only source of misinformation and inflammatory statements about migrants. Incendiary comments made by state officials are also contributing to the problem of xenophobia. Minister of Home Affairs Mangosutho Buthelezi, in his first introductory speech to Parliament, stated, "If we as South Africans are going to compete for scarce resources with millions of aliens who are pouring into South Africa, then we can bid goodbye to our Reconstruction and Development Program."16 In this same speech, Buthelezi called on local South African communities to assist his department in curbing the influx of foreigners by reporting suspected undocumented migrants. Police have also been accused of offering monetary rewards to local citizens in exchange for information about suspected "illegals." ${ }^{17}$

The role of state officials in promoting anti-immigrant sentiment among South Africans may, on initial consideration, seem contrary to the state's professed goal of racial equality. While it is unlikely that the inflammatory statements made by Buthelezi and other officials represent a concerted, state-sponsored attempt to demonize foreigners, the rise in xenophobia is in fact symptomatic of the objective to build a "Rainbow Nation" based on the principle of non-racial citizenship in South Africa. The explanation of this can be found in an understanding of what Croucher refers to as the difference between "constitutional engineering" and "cultural engineering." 18

\section{Constitutional Engineering since 1994: Restructuring South African Law}

"Constitutionally," South Africa has made impressive advances in granting universal human rights to both citizens and non-citizens. In addition to its ratification of the 1951 Refugee Convention, the 1967 Protocol, and the 1969 OAU Conventions mentioned above, South Africa has signed on to the UN Convention against Torture, the International Covenant on Civil and Political Rights, the Convention on the Rights of the Child, and the African Charter on Human and Peoples' Rights. ${ }^{19}$ Together, these represent one of the most far-reaching commitments to the values of universal human rights that a state has ever undertaken.

The 1996 Constitution draws no distinction between non-citizens and citizens for most rights, and specifies thirty rights accorded to all persons in its Bill of Rights. The rights restricted to citizens are the right to enter the country, to obtain a passport, to vote, to stand for office, to form a political party, and to exercise other political rights. ${ }^{20}$ The Constitution guarantees the right of human 
dignity to all individuals and outlines a number of rights granted to those in detention.

Although many of the rights contained in the Constitution have not yet been interpreted by a court of law, a unanimous judgment dealing with the rights of noncitizens found that they "were protected by the Bill of Rights' non-discrimination clause, and that all employment opportunities, with the limited exception of politically sensitive positions, should be available to permanent residents and South African citizens on an equal basis." ${ }^{21}$ The conclusion was that "the treatment of undocumented migrants, asylum-seekers, refugees, and other migrants in South Africa should be viewed in light of the protections provided by the Constitution's Bill of Rights as well as against international standards." 22

Outside the courts, however, the reality of life in South Africa for migrants is far less egalitarian. As mentioned above, those perceived as "foreigners" suffer frequent attack and are often scapegoated by the media and by politicians for the country's economic difficulties. The end of apartheid has not led to the expected redistribution of wealth. Consequently, South Africans who have yet to "taste the fruits of liberation" have blamed and been incited to blame those whom they perceive as foreigners. ${ }^{23}$ As South Africa struggles to realize its goal of building a "Rainbow Nation," the establishment of a non-racial citizenship has translated into an environment of resentment and fear of migrants. Redefining South African identity in the fledgling democracy has concentrated increasingly on the need to determine who is South African in opposition to who is not.

\section{Cultural Engineering: Reconstructing Identity and Nation Building}

Though academics debate the precise origins of the modern nation-state system, most agree that it developed in Europe and that the concept of national citizenship emerged as the "natural" joining of identity and rights at the time of the French Revolution. The state developed as the protector of citizens-a particular "nation" of people united by a sense of common purpose, race, language, etc., and located within a bounded territory. The concepts of nation and territory were integral to the definition of the nation-state and yet, in practice, combined in different ways to form various types of states.

In attempting to clarify the complex links that exist between nation and state, Buzan identifies four models: the nation-state, the state-nation, the part-nation-state, and the multination-state, which comprises both the federa- tive and the imperialist state models. ${ }^{24}$ In the first model, represented by states such as Japan, the nation precedes the state and is the driving force behind its creation. The second model, typical of the United States and Australia, is a top-down model in which the state plays an instrumental role in forming the nation. Buzan notes that while the state-nation model is most easily achieved when the state occupies a previously uninhabited or sparsely populated region, it also applies to states that attempt to unify multiple nations within their boundaries into one cohesive nation. The third model, the part-nation-state, occurs when a nation is divided between and dominant within two separate states, as was the case with North and South Vietnam. The multination-state comprises two or more relatively complete nations within its borders and is either federative, meaning that the nations exist separately and are allowed or even encouraged to pursue their own identities (exemplified by Canada), or imperialist, meaning that one nation dominates and controls the others (exemplified by the Russians' control of the former Soviet states). Not every state falls into one of these categories, but the models highlight the key links that exist in the relationship between nation and state.

During the apartheid era, South Africa functioned as what Buzan refers to in his classification of nation-states as an imperialist state-one in which one of the nations within the state (in this case, white South Africa) dominated the state structures to its own advantage. ${ }^{25}$ The South African state drew its sense of national purpose from ideas of racial preservation, and, as is clear from the history of South African migration policy outlined above, immigration and asylum policies were shaped according to the state's desire to define citizenship racially.

In 1994, South Africa confronted the immense challenge of restructuring its concept of nation. Although the political transition to democracy, marked by the drafting of the new constitution and the adoption of numerous international instruments based on human rights, was already under way, the path toward cultural and social reform was not as clearly delineated. In order to rid itself of the legacy of apartheid, the Government of National Unity (GNU) sought to redefine national identity. The former imperialist state was faced with the decision either to adopt a more federative multination-state system in which racial and ethnic diversity would be respected, or to pursue a state-nation model by constructing a nonracial identity that rejected the racial divisiveness of the past. The problem with the federative model, according to Croucher, was the potential threat it posed to the sta- 
bility and unity of the state, while the state-nation model ran the risk of "homogenizing, or not respecting cultural difference." ${ }^{26}$ Nelson Mandela, by embracing the idea of the "Rainbow Nation at peace with itself and the world," chose to lead South Africa on a path toward the formation of a state-nation, based on the ideal of non-racial reconciliation.

\section{Constructing a Non-Racial Nation}

The ability to create a sense of nation among a group of people hinges on the "constructivist" nature of identity and ethnicity. While a set of common values or characteristics must exist as a precondition to the formation of a nation, the concept of ethnic identity upon which it rests is open to interpretation and manipulation on many levels. "The definition of nation imposes no condition of permanence, and since both culture and race are malleable qualities, there is no reason why states cannot create nations as well as be created by them." ${ }^{{ }^{27}}$

In applying the "constructivist" approach to the South African case study, it is evident that, since 1994, the process of nation building within South Africa has relied heavily on both the "primordial" and "instrumental" aspects of ethnicity. Under the apartheid state, government officials invoked race as the defining characteristic in determining ethnicity. While the "primordial" nature of race is quite evident, it alone was not sufficient to guarantee the success of a policy that used race as the determinant of ethnicity. Even skin colour can blur across the black/white divide. The success of the apartheid state was due to its ability to manipulate state structures in support of its racist campaign.

Since the transition to democracy, the South African state has actively relied on the "instrumentalist" nature of ethnicity to redefine South African identity and construct a new concept of nation. The state has chosen to define ethnicity non-racially, and instead has focused on promoting national citizenship as the cultural determinant of South African identity. While many might argue that such a concept is inclusive of all South Africans, its acceptance has, in fact, denied basic rights to a large number of people within South Africa's borders and has promoted an atmosphere of fear and resentment toward a group of people who, during the apartheid regime, were accepted within South Africa.

The new concept of national identity has not materialized out of nowhere, of course. Certain cultural differences have always existed between those now considered
South Africans and the foreign-born individuals who have, increasingly, become the targets of xenophobia. The "primordial" differences in language and appearance between South African citizens and non-citizens have always been present, but have not, until recently, been used to define membership in the South African nation. For example, South Africa's long period of isolation under apartheid fostered a sense of alienation, shared by both whites and blacks, from the rest of the continent that is only now being made relevant. Referring to a recent episode of xenophobic violence in which 300 immigrants from Angola, Namibia, and Nigeria-many of them longtime residents in South Africa-were chased from the township of Dunoon by a group of local men, Lloyd Thomas, a Baptist minister and social activist in Cape Town, remarked, "We've always thought ourselves special and apart, and now Africa has invaded our lives. I suppose a backlash like the one in Dunoon was inevitable, wasn't it? We will probably be seeing more of them.". ${ }^{28}$

The rise in xenophobic feelings among those, both black and white, that are now defined as South Africans can also be understood as analogous to the way in which the process of globalization has harbingered the proliferation of ethnic conflicts throughout the world. While many predicted that the process of globalization would result in the demise of ethnic differences, as local communities increasingly came into contact with one another, the reality has proven quite different. Globalization, instead of causing cultural difference to become obsolete, has, in fact, increased its significance. For it is only in opposition to an "other" that cultural difference becomes relevant and can be used by political leaders to construct concepts of ethnicity. As Turton explains, "Globalization is a precondition of localization ... One cannot 'think' locally unless one already has an idea of a global context in which localities can co-exist." ${ }^{29}$

In a similar sense, the merging of racial identities into a single unified concept of nation in South Africa has necessarily resulted in increased attention being focused at the local level on who qualifies as South African and who does not. Whereas foreign-born Africans were once accepted and granted legal status within the Bantustans during apartheid, they are now targeted as "illegals" in the new South Africa. Just as globalization highlights the dissimilarities between local communities, the process of South African nation building has drawn attention at the local level to the cultural differences that exist between native and foreign-born people within South Africa. 


\section{Conclusion}

As the gap between the new government's efforts, in recent years, to restructure the South African state "constitutionally" and "culturally" continues to widen, the prevalence of xenophobia amongst South Africans has risen dramatically. On the one hand, the South African state, through its adoption of numerous international instruments, has exhibited its commitment to the principle of universal human rights enshrined in the documents. The values espoused, including the thirty rights granted to all persons as opposed to only citizens, in the 1996 Constitution's Bill of Rights represent a visionary attempt to separate South Africa from the legacy of apartheid and establish it as a liberal democratic state.

On the other hand, in order to claim legitimacy, the new South African state must be seen as representing the South African nation. The "natural" coupling of identity and rights, embodied in the concept of national citizenship, which has defined states since the time of the French Revolution, describes the relationship between the nation and the state as follows: "The principle of sovereignty resides essentially in the Nation: no body of men, no individual, can exercise authority that does not emanate expressly from it." ${ }^{30}$ In attempting to separate itself from the apartheid state that preceded it, the post-apartheid government has sought to redefine the South African nation non-racially. What once could be referred to as an "imperialist state" has now begun the transition to a "state-nation" model, predicated on the reconstruction of South African identity. The dissolution of the Bantustan system and its concomitant emphasis on internal borders has led to an increased awareness of and attention paid to the control of South Africa's external borders.

The process of nation building within South Africa, however, has not proven inclusive for all those residing in its borders. The state's new sense of nation has developed not only in opposition to those whom it tries to prevent from entering South Africa, but also in opposition to the large numbers of foreign-born people within South Africa whom it, by definition, has sought to exclude from national citizenship. While foreign-born people in South Africa are granted numerous rights on paper, in reality they are often denied their most basic rights due to the xenophobic attitudes of state officials and ordinary citizens alike.

The disparity in South Africa between the "constitutional" and "cultural" reform strategies is not unusual. As the process of globalization occurs and the culture and language of human rights becomes more prevalent, the traditional concept of national citizenship, understood as the union of identity and rights within a bounded territory, is being challenged. Soysal contends that, in the post-war era, "Rights that were once associated with belonging in a national community have become increasingly abstract, and defined and legitimated at the transnational level. Identities, in contrast, are still perceived as particularized and territorially bounded." ${ }^{31}$ In other words, as the culture of universal human rights is increasingly adopted throughout the world, the role of the state as the guarantor of rights is being limited. "While nation states and their boundaries are reified through the assertions of border controls and appeals to nationhood, a new mode of membership, anchored in the universalistic rights of personhood, transgresses the national order of things." ${ }^{2}$ In South Africa, "constitutional" reform has progressed in accord with the global culture of human rights, but "cultural" reform, expressed as nation building and the reconstruction of identity, has resulted in the limitation of rights to certain persons both inside and outside South Africa's borders.

Viewed in its historical context, it is possible to understand the intrinsic, yet tumultuous, role that migrants of all types have played in constructing South African identity since the country's creation. As the fledgling democracy struggles to claim legitimacy as the expression of the South African nation, the history of immigration and identity formation in South Africa continues to affect the country.

While President Mbeki refers to South Africa's participation in an "African Renaissance," the increasing levels of xenophobia within South Africa, due to the rift between the processes of "constitutional" and "cultural" engineering, thwart his efforts to foster solidarity with the rest of the African continent. This does not mean, however, that South Africa is necessarily doomed to regress into a state defined by its xenophobia and at peace with neither itself nor the world. South Africa has a long history as the economic force in Southern Africa and could potentially, acting in what Dolan refers to as its "enlightened self interest," help to lessen its attractiveness to foreigners by investing constructively in neighbouring countries. ${ }^{33}$ As host to the UN World Conference on Racism, Xenophobia, and Related Intolerance this summer, South Africa will gain legitimacy as a liberal democratic state and a contracting party to the universality of human rights. In order to actually achieve its objective of eliminating xenophobia and racial discrimination, however, the South African government must recognize that there 
exists an inherent contradiction between its desire to combat xenophobia and the fact that its success in building a South African nation hinges on its ability to construct its own identity in opposition to people from other African countries.

\section{Notes}

1. Constitution of the Republic of South Africa (1996), online: Index of South African Government Information <http:// www.polity.org.za/govdocs/constitution/saconst.html $>$ (date accessed: March 2001).

2. Jonathan Crush, "Contract Migration to South Africa: Past, Present, and Future" (1997), online: Southern African Migration Project $<$ http://www.queensu.ca/samp/transform/Crush .htm> (date accessed: March 2001).

3. Hennie Kotzé and Lloyd Hill, "Emergent Migration Policy in a Democratic South Africa," International Migration 35, no. 1 (1997): 7.

4. Crush, "Contract Migration to South Africa."

5. Francis Wilson and Mamphela Ramphele, Uprooting Poverty: The South African Challenge (Cape Town: David Philip, 1989), 197.

6. Economist, 4 March 1995, 40.

7. Human Rights Watch, Prohibited Persons: Abuse of Undocumented Migrants, Asylum Seekers and Refugees in South Africa (New York: Human Rights Watch, 1998), 25.

8. Human Rights Watch, Prohibited Persons, 27.

9. Sally Peberdy, "A Brief History of South African Immigration Policy" (background research paper for the green paper on international migration, 1997), 2.

10. Kader Asmal, Louise Asmal, and Ronald Suresh Roberts, Reconciliation through Truth: A Reckoning of Apartheid's Criminal Governance, (Cape Town: David Philip Publishers, 1996), 80.

11. Kotzé and Hill, "Emergent Migration Policy," 8.

12. National Consortium on Refuge Affairs, "National Plan of Action for 1999: Roll Back Xenophobia” (1998), online: South African Human Rights Commission <http:// www.sahrc.org.za/national_plan_of_action.htm $>$ (date accessed: March 2001).

13. Robert Mattes, Donald Taylor, David McDonald, et. al., "Still Waiting for the Barbarians: SA Attitudes to Immigrants \& Immigration," Migration Policy Series 14, online: Southern African Migration Project <http://www.queensu.ca/samp/ publications/policyseries/acrobat14.pdf $>$ (date accessed: March 2001).

14. Human Rights Watch, Prohibited Persons, 54.

15. Ransford Danso and David McDonald, "Writing Xenophobia: Immigration and the Press in Post-Apartheid South Africa," Migration Policy Series 17, online: Southern African Migration Project <http://www.queensu.ca/samp/publications/policyseries/acrobat17.pdf $>$ (date accessed: March 2001).

16. Mangosuthu Buthelezi, "Minister of Home Affairs: Introductory Speech, Budgetary Appropriation," National Assembly, 9 August 1994, in Human Rights Watch, Prohibited Persons:
Abuse of Undocumented Migrants, Asylum Seekers and Refugees in South Africa (New York: Human Rights Watch, 1998).

17. Human Rights Watch, Prohibited Persons, 47.

18. Sheila Croucher, "South Africa's Illegal Aliens: Constructing National Boundaries in a Post-Apartheid State," Ethnic and Race Studies 21, no. 4 (1998), 640. Croucher develops her theory using the terms constitutional engineering and cultural engineering, coined by Horowitz and Mazrui, respectively.

19. Jonathan Klaaren, "A Guide to South African Refugee Law" (1999), online: A Guide to South African Refugee Law <http:// www.law.wits.ac.za/school/klaaren/sareflaw.htm> (date accessed: March 2001).

20. Constitution of the Republic of South Africa.

21. Human Rights Watch, Prohibited Persons, 160.

22. Ibid.

23. Croucher, "South Africa's Illegal Aliens," 642.

24. Barry Buzan, People, States and Fear: The National Security Problem in International Relations (Brighton, Sussex: Wheatsheaf Books, 1983).

25. Ibid., 48 .

26. Croucher, "South Africa's Illegal Aliens," 647.

27. Buzan, People, States and Fear, 45.

28. Quoted in Paul Salopek, "Intolerance in 'Rainbow Nation,"” Chicago Tribune, 16 January 2001.

29. David Turton, "War and Ethnicity: Global Connections and Local Violence in North East Africa and former Yugoslavia," Oxford Development Studies 25, no. 1 (1997), 86.

30. National Assembly of France, "Declaration of the Rights of Man and of the Citizen" (1789), online: The French Revolution $<$ http://members.aol.com/agentmess/frenchrev/mancitizen .html> (date accessed: March 2001).

31. Yasemin Soysal, "Changing Citizenship in Europe," in Citizenship, Nationality and Migration in Europe, eds. David Cesarani and Mary Fulbrook (London: Routlege, 1996), 18.

32. Ibid.

33. Chris Dolan, "Aliens Aboard: Mozambicans in the New South Africa," Indicator South Africa 12, no. 3 (1995).

Janet Reilly recently received her master's degree in forced migration from the Refugee Studies Centre at Oxford University. Through the support of the Hart Fellows Program at Duke University, she has worked with Save the Children Federation and UNHCR in Ethiopia and Guinea, respectively, and has worked with refugee resettlement in the United States. 